\title{
Lancashire Conservatives, Tariff Reform and Indian Responsible Government*
}

\section{N.C. Fleming}

\section{Introduction}

Lancashire Conservatives played a highly visible part in disagreements over party policy and identity in the first half of the twentieth century. In the Edwardian period, they stood squarely against attempts by the Tariff Reform League to change the party's fiscal policy. In the early to mid-1930s, the question of Indian responsible government drove a wedge through Conservatism in Lancashire, but far from diminishing its voice in the party, the uncertainty it produced ensured that Lancashire Conservatives were courted by ministers in the National Government as well as diehard Conservatives. The majority of Lancashire's Conservative MPs were in favour of the India white paper published in 1933, but the largest body of Conservative opinion in the northwest, the Lancashire, Cheshire and Westmorland Divisional Association, expressed serious reservations and objections.1 Lancashire's dependence on cotton exports to India accounts for its prominence on each occasion, as does the Conservative party's electoral success in a heavily industrialised and densely populated county. This not only made Lancashire an important example of Conservative claims to represent 'one nation', but the vulnerability of many seats made it essential to carry local opinion. Lancashire's conspicuousness in Conservative party

\footnotetext{
* An earlier version of this article was presented as a paper to the Historic Society of Lancashire and Cheshire, Liverpool Central Library, 19 November 2014. The research was supported by a Scouloudi Research Award, Institute of Historical Research, University of London, a Research Grant, Historic Society of Lancashire and Cheshire; an Associate Fellowship, Institute of Commonwealth Studies, University of London, and an Honorary Research Fellowship, School of History, Archaeology and Religion, Cardiff University. The author would like thank the Conservative Party for granting permission to quote from its records held at the Bodleian Library, and to acknowledge the helpful advice and assistance of Stuart Ball, Derek Fleming, Jeremy McIlwaine, Nick White, and the two anonymous referees for Contemporary British History.

1 The Lancashire Divisional Association amalgamated with the Cheshire Divisional Association in 1925, and in 1929 absorbed the Westmorland Divisional Association. The Lancashire, Cheshire and Westmorland Divisional Association was alternatively referred to as the North Western Area. This article refers throughout to the 'Lancashire division' for consistency and convenience.
} 
debates about tariff reform and India is acknowledged by scholars, but in separate historiographies that tend to overlook several important features: the gradual abandonment of free trade by Lancashire Conservatives in favour of imperial preference; the relevance of this reappraisal of the fiscal question to the party's debates on Indian responsible government; the continuing importance of local politics and the party's regional identity; and the significance of the democratising forces of labour and women to the party's success on the ground.

Historiography on the Conservative party and India tends to present Lancashire as the site of a wider struggle within the Conservative party centred on Westminster. 2 This adheres, intentionally or otherwise, to a high politics approach that dismisses party opinion 'as malignant or beneficial forces with unknown natures and unpredictable wills.' 3 The county is, of course, relevant to the broader debate among Conservatives about India's future, but viewing its role from the perspective of Westminster rather than Lancashire tends to overlook and undermine the relevance of local attitudes to political, social and economic questions, and in particular, Indian responsible government. Scholarship on local Conservatism remains limited, despite the inter-war party bequeathing 'the richest archival record of any British political party in any historical period.' 4 N.J. Crowson observes that overlooking local party records reinforces the assumption that Conservative associations existed only for ceremonial purposes and supplying canvassers at election times. 5 In a like manner, David Thackeray argues that it is necessary to study local Conservative activism to understand the party's electoral success in industrial areas. 6

The surviving records of Lancashire Conservatives make it possible to develop a layered understanding of the party crisis over India. Correspondence between the county's leading figures discloses their anxiety about carrying local opinion. The minute books of the area

\footnotetext{
2 Ghosh, 'Decision-Making'; Peele, 'Revolt over India'; Bridge, Holding India; Stewart, Burying Caesar, Muldoon, Last Act of the Raj; Fleming, 'Diehard Conservatism'.

3 Cowling, Impact of Labour, 3.

4 Ball, Portrait of a Party, 1, 145-248. See, Aubel, 'Welsh Conservatism'; Bates, 'Conservative Party'; Ball, 'National and Regional Party Structure'.

5 Crowson, Facing Fascism, 5-6.

6 Thackeray, 'Home and Politics'.
} 
council—which had representatives from every constituency association, and the parallel bodies for women, youth and labour-provide an overview of opinion in the region, and also contain revealing reports of acrimonious resolutions, failed resolutions and amendments. As council delegates tended to be drawn from the more prominent, committed and leisured of the membership, it is necessary also to investigate a sample of the surviving records of constituency associations and allied bodies. Not all of these address India. This is not unexpected in areas which had little or no direct connection to cotton manufacturing, but it requires further explanation in the case of mill towns such as Darwen. It is possible that some association committees confined their business to administration, or that their secretaries were reluctant to record political discussions. 7 It is also conceivable that association officers were wary of addressing India, lest it expose divisions in their own ranks. The No. 4 Group of the Women's Unionist Association, for example, ignored the offer of a speaker on India from the Lancashire division's Women's Advisory Committee, and withdrew a session on the controversy planned for its 1934 conference. 8 As this suggests, the records provide information on gender, but there is very little on the social and economic background of party members. Stuart Ball observes that working-class men were less likely to join constituency associations or retain membership as 'the atmosphere of some branches could seem alien and unwelcoming, and their activities mainly middle class in nature.'9 This is consistent with research on the demography of party memberships.10 It is important to note, however, that Lancashire Conservatism was not confined to constituency associations; it cultivated a network of Working Men's Associations and labour advisory committees, and organised social activities for 'factory' women.

\footnotetext{
7 Darwen Division of Lancashire Conservative and Unionist Registration Association, Minutes of Various Committees 1914-37, Lancashire Archives, PLC 2/2/4.

8 No. 4 Group of the Women's Unionist Association Minutes 1921-1936 [No. 4 Group], 26 May 1933, 30 January 1934, 14 September 1934, Lancashire Archives, PLC 2/2/5 [hereafter PLC 2/2/5]; Northwestern Area Women's Advisory Committee [NAWAC], Meeting, 5 December 1934, Conservative Party Archive, Bodleian Library, Oxford, ARE/3/11/1 [hereafter ARE/3/11/1].

9 Ball, Portrait of a Party, 163.

10 Scarrow, 'Political Activism and Party Members', 642.
} 
The relationship between Lancashire and India is examined in number of studies. Basudev Chatterji's Trade, Tariffs, and Empire examines the inter-war decline in cotton exports. Lancashire's textile industry was strategically important to the British economy in the nineteenth century, and in contrast to other exporters, it experienced absolute growth in the 1880 s, mainly to the expanding Indian market. The resulting influence of Lancashire manufacturers on Indian economic affairs came to an abrupt end in 1917, when Britain permitted the government of India to set its own tariffs. Thereafter, cotton exports to the subcontinent declined, from 3,000 million yards in 1913 to 145 million yards in 1939.11 P.J. Cain and A.G. Hopkins argue that this decision demonstrates the waning political influence of Lancashire's manufacturers and also of provincial politics more generally.12 Their thesis has not gone unchallenged; in the case of Lancashire, Andrew Muldoon argues that the county still had symbolic importance to the Conservative party.13 The Secretary of State for India, Sir Samuel Hoare, believed that it bolstered the party's self-image of representing one nation, and he worked behind the scenes in the early 1930s to secure a cooperative attitude on the part of cotton manufacturers in both Britain and India.

Martin Pugh published a response to Muldoon which aspires 'to give voice to local politics and the Lancashire MPs who hardly figure in Muldoon's account'.14 It examines the correspondence between the MP for Wallasey, John Moore-Brabazon, and the chairman of his constituency association, and provides some observations about the potential electoral challenge posed by the British Union of Fascists (BUF). Pugh makes several claims from this very limited sample of local records: that rebellious MPs could be reined in by local officials as well as party whips, even if they had the support of ordinary members; that textiles were not mentioned in discussions about India and therefore that Indian policy was seen as a matter of party unity and loyalty to the leader; that the BUF had no difficulty outflanking Lancashire Conservatives on

\footnotetext{
11 Chatterji, Trade, Tariffs and Empire, 1, 8, 337-345.

12 Cain and Hopkins, British Imperialism, 543, 549-550.

13 Potter, British Imperial History, 33; Muldoon, 'Unholy Row'.

14 Pugh, 'Lancashire, Cotton, and Indian Reform', 144.
} 
India; and that Conservative success in Lancashire at the 1935 general election is explained by the BUF's refusal to stand and the former appropriating the fascists' arguments. These conclusions are revised significantly by the evidence presented in this article. Just as local officials could rein in MPs, so they could be outflanked and outnumbered by ordinary members through majority resolutions. Far from not being mentioned, discussion about India amongst Lancashire Conservatives was dominated by textiles. This in turn makes Pugh's claims about the BUF untenable.15 Indeed, the surviving records indicate that Lancashire Conservatives were alive to the spectre of fascism, as well as the need to reassure the Jewish population of Conservative support.16 The real battle on the right was played out in late January and early February 1935, when a by-election at Liverpool Wavertree brought forth two rival Conservative candidates, an event not mentioned in Pugh's account.17 Local fascists criticised both men, reserving particular venom for the Independent Conservative, Randolph Churchill, describing him as a 'bell-hop for the Jews' and a stooge for Lord Rothermere.18 Sir Oswald Mosley declined to put up his own candidate at the by-election, claiming that his party was 'serious' and 'not looking for harlequinades.' 19

Pugh is correct to highlight the importance of loyalty to Conservatives. However, the records demonstrate that Lancashire Conservatives did not regard their criticism of the government's India policy as disloyal. Loyalty in the party, of course, was more typically relayed through quiescence, even silence, on controversial issues, but even when activists revolted, loyalty could be maintained if members felt that they had a fair hearing.20 The Lancashire division's area council was far from quiescent, but its resolutions criticising the India white paper did not call the leadership or the consultative process into question. The loyalty of Lancashire Conservatives

15 For critique of Pugh's approach to the BUF and Conservatives see Williamson, 'Conservative Party, Fascism and Anti-Fascism'; Fleming, 'Diehard Conservatives'.

16 Middleton, Prestwich, and Whitefield Conservative Association Finance and General Purposes Committee [Prestwich CA committee], 28 June 1934, 26 July 1934, Middleton, Prestwich, and Whitefield Minute Book, 1928-41, Lancashire Archives, PLC 1/2 [hereafter PLC 1/2].

17 Waller, Democracy and Sectarianism, 335-337; Dutton, 'A Mad Hatter Contest'.

18 Blackshirt, 15 Feb. 1935, 3, 6; 5 Apr. 1935, 7.

19 Blackshirt, 18 April 1935, 5.

20 Harrison, Separate Spheres, 241; Norton and Aughey, Conservatives and Conservatism, 258. 
to the party leader is evident also in how they handled diehard Conservatives. Diehard MPs numbered around thirty to forty in the inter-war period. They were distinguished from the rest of the parliamentary party by regularly being at odds with the front bench over the direction and aims of party policy, especially concerning the constitutional and strategic reorganisation of the empire. There was some cooperation between a section of Lancashire Conservatism and a small number of diehard parliamentarians, but they parted company in June 1934 when the former expressed alarm about Winston Churchill's brazen challenge to party and parliamentary procedures. Even before this, the diehards' rhetorical embrace of Lancashire was never fully reciprocated. Cotton exports might have featured prominently in diehard propaganda and speeches, but the resolutions passed by the Lancashire division remained focussed on this specific concern and avoided any judgement about India's capacity for self-government.

To examine the significance of the stance adopted by Lancashire Conservatives over India, it is instructive to first consider the nature of the party's support and operations in the county during the inter-war years, including the response of local leaders to the democratising forces of women and labour. The article then locates the position of Lancashire Conservatives on India within the long running party controversy over tariff reform, examining how party members altered their attitude to tariffs considerably by the late 1920s in the hope that it might stall declining cotton exports. It was their realisation that the 1932 Ottawa agreements would have little or no effect that led Lancashire Conservatives to express anxiety about Indian responsible government. Finally, the article charts the events immediately leading up to the Wavertree byelection. This episode demonstrates the irrepressibility of local concerns, despite Randolph Churchill's call on Wavertree to trigger a wider Conservative renewal, and the leaderships' attempt to make the by-election a vote of confidence in the National Government. Lancashire Conservatives were not simply passive or vulnerable to the machinations of Westminster politicians, and although the government was able only to offer weak concessions on cotton exports, the defiant stand adopted by the area council maintained the party's credibility locally, 
especially amongst cotton mill workers. As a result, the local party performed better than expected at the 1935 general election in spite of the India Act.

\section{Lancashire Conservatism}

The Conservative and Unionist party flourished in Lancashire and Birmingham before the Great War, though the two industrial areas were associated with contending positions on the fiscal question.21 Joseph Chamberlain's panacea of tariff reform appealed to Conservatives across the country, but it was strongly resisted by free trade Lancashire, where 'food taxes' were regarded as an electoral liability. Tory democracy had deep roots in Lancashire, and proved resistant in the 1880s and 1890s to Chamberlain's Liberal Unionists.22 The success of New Liberals, in contrast, rendered the county 'the cockpit of Edwardian elections', and inclined most of its Conservatives, including the seventeenth Earl of Derby, to express hostility to the party's drawn out preoccupation with tariff reform.23 The Conservative leader, Arthur Balfour, tried to reconcile Lancashire opinion with tariff reformers by pledging to hold a referendum on tariffs. It satisfied Derby but tariff reformers questioned its continuance. The former toyed with establishing a separate crusade against food taxes, and warned in December 1912 that the abandonment of the referendum pledge by Balfour's successor, Andrew Bonar Law, meant that hundreds were deserting the Conservatives in Lancashire. A short term solution emerged in January 1913 when the party adopted the 'Ashton formula'. Named after Law's speech at the Lancashire mill town of Ashton-under-Lyne, it declared that a Conservative government would wait for any initiative on tariff reform to come from the colonies. Neither side was happy with the compromise, but the protracted wait for Derby's approval obliged the tariff reformers to back down for the sake of party unity.24

\footnotetext{
${ }_{21}$ Green, Crisis of Conservatism, 274-279.

22 Pelling, Social Geography of British Elections, 239-287; Cawood, Liberal Unionist Party, 131-134.

${ }_{23}$ Clarke, Lancashire and the New Liberalism, vii; Dutton, 'Lancashire and the New Unionism'.

24 Blewett, Peers, the Parties, and the People, 204; Dutton, 'His Majesty's Loyal Opposition', 189-192.
} 
Senior Conservatives at Westminster regarded Derby as the 'undisputed leader' of Lancashire Conservatives. He in turn was usually deferential to them, but his identification with Lancashire led on several occasions to breaches with the party leader. Derby's presidency of the Lancashire division was not merely ornamental. He regularly attended the quarterly meetings of its area council, corresponded with leading political figures in the county, and on occasion contributed to the election expenses of local candidates.25 Derby had been the MP for Westhoughton (1892-1906) before succeeding to the earldom, and held junior ministerial offices between 1900 and 1905. Brought into the wartime coalition government in July 1916 as Under Secretary of State at the War Office, Derby was promoted six months later to Secretary of State. He did not serve in the post-war coalition, but accepted Law's invitation to return to government in October 1922, in an administration which defied recent social changes by being 'astonishingly' aristocratic in its composition. 26 Derby's omission from the Conservative cabinet formed in November 1924 was sufficiently significant to prompt the Foreign Secretary, Austen Chamberlain, to express anxiety about the lack of representation from Lancashire. The Chamberlain bailiwick of Birmingham, in contrast, had four seats at the cabinet table.27 Lancashire remained an electoral battleground after 1918. Labour's arrival as a serious political force led to vigorous three-corned fights, and a marked variation in general election performances for the Conservatives. At the 1923 and 1929 general elections, a swing to Labour deprived Conservatives of many seats, aiding the return of minority Labour governments at Westminster. But swings away from Labour, in 1924 and 1931, restored Conservative fortunes and returned the party to government. In part, Conservative support in Lancashire reflected an enduring association between politics and denominationalism that marked the county out from other regions of England. According to Peter Clarke, Anglicanism's appeal to a large section of

25 Ball, Portrait of a Party, 244, 303, 414-415.

26 Cannadine, Decline and Fall of the British Aristocracy, 210.

27 Ball, Portrait of a Party, p. 405. Derby's two sons, Lord [Edward] Stanley and Oliver Stanley, both MPs, became cabinet ministers, respectively, in 1938 (for a few months before his death) and 1933. In May 1940, Churchill replaced Oliver Stanley with Anthony Eden as Secretary of State for War. 
the urban working class 'ran a straight and narrow course between the Dissent of the bosses and the Roman Catholicism of the Irish immigrants'.28 In Manchester and Liverpool, electoral support for Conservatism was stronger among the working class than the middle class. 29 The party's continuing strength in Lancashire is also linked to the predominance of women in the cotton mills.30 At its height, the industry employed half a million full time workers in the county.31 Rising unemployment amongst female cotton workers helped to restore Conservative fortunes at the 1931 general election; the party took 90 per cent of Lancashire's sixty seats in support of the National Government, though many of its gains were marginal.32

Denominationalism had to be allied to a more responsive attitude to the working-class electorate if Conservatives were to meet the challenge of Labour. This was not a new realisation although the scale of the task grew considerably after 1918. In the early nineteenth century, the Orange Society combined anti-Catholicism with the cause of Lancashire mill workers. 33 In the era of the Second and Third Reform Acts, Conservative Working Men's Associations were formed to harness the support of new voters. 34 The success of these associations in Liverpool owed much to Arthur Forwood and his protégé, Archibald Salvidge, who appealed to class identities and demanded greater representation for working men.35 Denominational identity still mattered, even into the 1930s; senior figures might complain about its excesses, but the risk of alienating working-class Protestant voters kept these concerns in check.36 The launch in Lancashire of the Unionist Labour Movement in 1919, and the success of its Labour Advisory Committees, therefore built on a long history of working-class mobilisation in the county, albeit

\footnotetext{
${ }_{28}$ Clarke, New Liberalism, 53.

29 Dutton, 'Lancashire', 133.

30 Ball, Portrait of a Party, 121-122.

31 Chatterji, Trade, 9.

32 Muldoon, 'Unholy Row', 100.

33 Sack, From Jacobite to Conservative, 108; Davies and Morley, 'The Politics of Place', 72.

34 Lee, 'Conservatism, Traditionalism and the British Working Class'.

35 Turner, 'Re-thinking Popular Conservatism in Liverpool'.

36 Belchem, Irish, Catholic and Scouse, 301-303. See, Derby Papers, Liverpool Record Office, 920 DER (17) [hereafter 920 DER (17)], in particular, correspondence with Sir Thomas White, 920 DER (17) 6/33, and Sir John Shute, 920 DER (17) $11 / 1$.
} 
cast in new and ostensibly secular terms to meet the arrival of Labour as an electoral force.37 In May 1932 the Lancashire division's area council carried a motion deploring 'the absence of Conservative Wage-earning representatives in the present Parliament.' 38 Lancashire Conservatives were typically hostile to 'socialist' influence in trade unions and readily supported the 1927 Trade Disputes Act, yet they were also acutely conscious of the danger of working class solidarity in the face of coercive legislation. 39 In November 1932 the area council carried a motion urging the Minister for Labour

to consider introducing legislation to enable him to be more lenient than at present with those workers who during the recent Cotton Strikes found themselves, through intimidation and mob rule, unable to work and also after 'signing on' unable to draw 'dole', thus turning those who were constitutionally minded British wage-earners into very bitter opponents of our Government.40

The issue of 'unfairly penalised workers' was raised again by Lancashire Conservatives during the passage of the 1933 Unemployment bill.41

The progress of women in Lancashire Conservatism was gradual and uneven. In contrast to other parts of the country, the Primrose League was not able to adequately provide opportunities for middle- and upper-class women activists in the county. The league was popular among cotton workers in mill towns, but the lack of a substantial local Tory elite, alongside the dominance of the Working Men's Conservative Association in Liverpool, deprived Primrose

\footnotetext{
37 Ball, Portrait of a Party, 159, 269; Davies and Morley, 'Politics of Place', 73-74

38 Lancashire and Cheshire Divisional Association [LCDA] Minutes, 1925-32, Quarterly Meeting, 7 May 1932 , Conservative Party Archive, Bodleian Library, Oxford, ARE/3/1/1 [hereafter ARE/3/1/1].

39 LCDA, Quarterly Meeting, 17 January 1931, ARE/3/1/1; Lancashire and Cheshire Federation of Junior Unionist Associations [LCFJUA]: Minutes, 1910-1935, AGM, 30 April 1927, Conservative Party Archive, Bodleian Library, Oxford, ARE/3/16/3 [hereafter ARE/3/16/3].

40 LCDA, Quarterly Meeting, 19 November 1932, ARE/3/1/1.

${ }_{41}$ Clitheroe Division Conservative Association [Clitheroe CA] Executive Committee meeting, 29 November 1933, Lancashire Archives, DDX 800/1/2 [hereafter DDX 800]; No. 4 Group Committee Meeting, 1 December 1933, PLC 2/2/5.
} 
dames of the necessary networks to extend their influence.42 Even after the limited extension of the franchise to women, moves to treat them as integral members of local party organisations met with resistance. The records for Lancashire confirm David Jarvis's observation that male activists were ambivalent about women's participation in the Conservative party, hailing it as a success for Tory democracy, but also expressing deep concern about the 'feminization' of grassroots Conservative politics. 43 This ambivalence meant widely varying responses to women's participation in the early 1920s; whilst some associations approved procedural changes to guarantee women a proportion of representative positions, others declined to admit them as members.44 The Lancashire and Cheshire Federation of Junior Unionist Associations fell into the latter category. It finally reversed its stance in 1925 following continued efforts by delegates from Ashton, and the decisive intervention of Derby’s heir, Lord Stanley.45 Miss M.L. Jackson emerged soon after as a prominent member, becoming one of the Junior Conservatives' two vice chairmen in 1928 and regularly chairing its general purpose committee in the 1930s.46 The increased participation of women encouraged some to attempt to re-shape the practices of the Lancashire division. In 1931 two prominent women members, the Hon. Mrs Hornyold and Lady Maureen Stanley, with the backing of representatives from the party's Teachers Circle and Liverpool Working Men’s Association, succeeded in securing the Lancashire division's unanimous agreement

to pay travelling expenses of members attending the Meetings in London of the Central Council and the Executive Committee of the National Union, and also to

\footnotetext{
42 Pugh, Tories and the People, 122-125; Cowman, Mrs Brown is a Man and a Brother, 43-44.

43 Jarvis, 'The Conservative Party and the Politics of Gender'.

44 Cheshire Division 1918-1925, Executive Committee meeting, 6 January 1923, Conservative Party Archive, Bodleian Library, Oxford, ARE/3/6/3.

45 LCFJUA, AGM, 10 September 1921, 1 March 1924, 21 March 1925, 30 April 1927, ARE/3/16/3. The

Conservative Archive only contains minutes from the Junior Conservatives and not the Lancashire Junior Imperial League. Some delegates to the former felt that there was 'considerable overlapping in the organisations and that the facilities and services of the Junior Imperial League are much more advantageous than those of the Junior Unionist Organisation', see, LCFJUA, AGM, 30 April 1927, ARE/3/16/3.

46 LCFJUA, Special General Meeting, 12 November 1927; LCFJU, AGM, 31 March 1928, ARE/3/16/3; LCFUA, General Purpose Committee Minutes, 1912-1940, ARE/3/16/2.
} 
pool such expenses, feeling confident that this will ensure a fuller and more democratic representation from all parts of England and Wales irrespective of distance from London, or the private means of members. 47

The region's Women's Advisory Committee provided a forum specifically for women and coordinated the activities of women's associations throughout the northwest of England. It regularly issued suggestions for subjects to be discussed by women's branches, including 'India', though as noted above, at least one women's committee declined its offer a speaker on that topic. 48 The advisory committee even hosted a talk on the 'Indian women's franchise', by Irene Ward, MP for Wallsend, though there is no further record of the subject in their minutes. 49 It took a particular interest in education, discussed the major political issues of the day, and actively participated in meetings of the area council. The advisory committee's education work took several forms. The most well-known was its organisation of 'week-end political schools' to train party members. It also discussed forming reading groups to combat 'Communist propaganda carried on through the Left Book Club'.50 Its mission to educate extended to female factory workers. This particular endeavour fulfilled the role model projected in party propaganda of older worldly women addressing the 'alarming ignorance' of their younger counterparts.51 As a 1935 report notes:

There are certain difficulties inherent in work among girls which all social workers agree upon, and which make spectacular effects unlikely. There is an absence of good home influence among the girls we are trying to enrol, while fewer outlets are

\footnotetext{
47 LCDA Quarterly Meeting, 25 April 1931, ARE/3/1/1. The pooling of expenses had previously been rejected by Junior Conservatives, see, LCFJUA AGM, 16 March 1912, ARE/3/16/3.

48 NAWAC, Meeting, 5 December 1934, ARE/3/11/1.

49 NAWAC, Meeting, 29 November 1933, ARE/3/11/1.

50 NAWAC, AGM, 17 June 1937, ARE/3/11/1. It complained about BBC broadcasts on Russia, see, NAWAC, AGM, 20 Jan. 1938, ARE/3/11/1.

51 Jarvis, 'Mrs Maggs and Betty'.
} 
provided for their youthful spirits than are offered to boys ... The National "Keep fit" movement has been created to supply a need among girls, and our organiser has established friendly relations with several of their organisers... 52

The utilisation and emulation of non-party associational culture was typical of female Conservative activism in the inter-war period, especially in industrial areas, as it provided a means to break down social barriers and reach the new electorate. 53

The progress of women in Lancashire Conservatism should not be overstated. The party did not merely adapt passively to meet female political interests, it also attempted to shape the identity of women in its own image. 54 Moreover, women's progress continued to encounter opposition. A discussion among Prestwich Conservatives in 1928, about 'engaging lady speakers', was left in 'abeyance' and not considered again. 55 Four years later, a proposal at the area council to allow allied women's organisations to nominate representatives was diluted to recommendation.56 Women Conservatives in Liverpool complained in 1933 about being prevented from entering a Conservative Club during a meeting of the working men's association. 57 Even so, the ill-disposition of some male activists did not prevent women from playing a visible role at the highest level of Conservative organisation in the county, the area council. The records suggest that this large assembly was a more conducive forum for women's participation than most constituency associations. This is demonstrated by the regular intervention of women delegates in discussions on party procedures and policy, and the election in 1934 of Mrs R.C. Assheton CBE as chairman.58 The advancement of women at provincial

\footnotetext{
52 NAWAC, Report of the Women's Advisory Committee for June, 1934, to May, 1935, ARE/3/11/1. 53 Thackeray, 'Home and Politics', 835.

54 Jarvis, 'Mrs Maggs and Betty', 130-131.

55 Prestwich CA committee, 5 July 1928, PLC $1 / 2$.

56 LCDA Annual Meeting, 23 July 1932, ARE/3/1/1.

57 Liverpool Women's Unionist Federation, Executive Committee, 28 April 1933, Liverpool Constitutional Association Records, Liverpool Record Office, 329 CON/1/8/2 [hereafter 329 CON/1].

58 LCDA, Quarterly Meeting, 13 October 1934, ARE/3/1/1.
} 
level was supported by Derby and his family. ${ }^{9}$ Given the earl's growing unease about militant Protestantism and the rowdiness of public meetings, he may have anticipated that a greater role for women would encourage the development of peaceable politics in Lancashire.60 The evidence for such an effect is indeterminate, but it is clear that the presence of a significant proportion of women on the area council did not diminish its independence when in conflict with the party leadership, as demonstrated during the party crises over fiscal policy (1930-31) and Indian responsible government (1933-35).

\section{The Abandonment of Free Trade}

The campaign for tariff reform persisted after the Great War. Economic and industrial decline in Lancashire, especially in cotton manufacturing, rendered the county's Conservatives more equivocal in their attitude. They remained wary of food taxes, but the imposition of tariffs by the Indian government from 1917 increased the appeal of an imperial trade agreement to lower tariffs across the empire. It was hoped that this might protect shrinking export markets, as well as allow Lancashire cotton to dominate developing markets in Africa. The gradual change in their attitude to the fiscal question was first evident in 1923, when Law's successor, Stanley Baldwin, made tariff reform part of his platform at the general election called for 6 December. The prime minister outlined his new position beforehand in Manchester's Free Trade Hall, at a meeting which was billed in advance as the 'most important landmark in the development of the Government's policy.' Chairing the meeting, Derby introduced Baldwin's speech by cautioning the audience, 'we have got to think over it.' ${ }_{61}$ Afterwards, at a meeting of Lancashire's Conservative MPs, half a dozen expressed concern about the apparent departure from free trade, though a majority were persuaded by Derby's reassurance that the proposals were 'an emergency measure to meet an abnormal situation', and that he would lay their concerns before the prime

59 LCFJUA, AGM, 21 March 1925, ARE/3/16/3; Derby to White, 12 February 1929, 920 DER (17) 6/34. 60 Derby to White, 25 April 1933, 8 November 1935, 11 November 1935, 920 DER (17) 6/34; Lawrence, Electing Our Masters, 120-129.

${ }_{61}$ The Times, 29 October 1923, 12; Churchill, Lord Derby, 525. 
minister. ${ }_{2}$ Derby subsequently reassured Conservatives at Northwich that there was 'no question of anything which is in the ordinary consumption of the people of this country being taxed', and that each industry which sought to increase tariffs must demonstrate that it is being unfairly treated'.63 Derby's position was boosted by news that the industrialist, Samuel Turner, had 'converted' to tariff reform, on the basis that it was necessary to encourage the sourcing of raw cotton within the empire.64 Yet Derby's support for the prime minister's policy was mocked in several quarters, even within his own party. Winston Churchill declared that Baldwin had 'carefully shrouded' his proposals in mystery, 'so that Lord Derby could run about Lancashire and say it was only to meet a temporary need, while the Prime Minister could say at Worcester that they would want it in the remote future.' 65

The party's defeat at the polls led to recrimination in Lancashire. Salvidge publicly demanded an investigation into the relationship between Central Office and the voluntary party. Derby felt obliged to summon a meeting of the area council to account for his recent actions. 66 The seven hundred delegates in attendance demanded that protection be dropped as party policy, and requested more effective communication between Central Office and constituency organisations. 67 It was a personal blow for Derby, but Lancashire's remarkable act of defiance actually helped Baldwin to abandon tariff reform without losing face, and adopt instead the less controversial policy of 'safeguarding' specific industries. Pressure for imperial preference remained, however, and swelled in the wake of the Conservative's defeat at the May 1929 general election.68 The press baron, Lord Beaverbrook, repackaged protectionism as 'Empire Free Trade', and his accompanying campaign played on the widespread feeling amongst Conservatives that Baldwin was out of touch and failing in the role of opposition leader. Lancashire's

\footnotetext{
62 The Times, 15 November 1923, 12.

63 The Times, 17 November 1923, 12.

64 The Times, 26 November 1923, 9.

65 The Times, 27 November 1923, 20.

66 The Times, 18 January 1924, 14.

67 The Times, 11 February 1924, 13.

${ }_{68}$ Ball, Baldwin and the Conservative Party; Williamson, National crisis and National Government.
} 
Conservatives initially sympathised with Baldwin's concern that food taxes might risk the party's electoral recovery in industrial areas. At a meeting of the area council on 26 October 1929, delegates resolved unanimously to express their 'unabated confidence in his leadership'.69 At the next quarterly meeting, however, a motion brought by delegates of the Women's Advisory Committee, and endorsed by the wider membership, 'respectfully' urged Baldwin to give 'an early declaration' on the fiscal question which 'would be of great help and encouragement to his supporters and workers.' 70

Baldwin's efforts between March 1930 and March 1931 to reach an understanding with tariff reformers heightened tensions in the party. Lancashire came out early in support of maintaining the compromise policy of safeguarding.71 In July 1930 the area council unanimously endorsed a resolution assuring Baldwin of 'its loyal support in the policy of industrial safeguarding and agricultural assistance and Imperial economic development'.72 Derby's authority helped to secure this declaration, but it did not prevent some delegates expressing frustration with council officers and Baldwin's leadership. These critics were more vociferous at the next quarterly meeting, on 4 October, making repeated attempts to overturn a decision by the chairman, Sir Alan Sykes, MP for Knutsford, to rule out of order any discussion on party policy 'without due notice being given.' This led to a successful motion requesting a 'special meeting ... to consider and discuss a resolution to be sent to our Leader outlining our views on the fiscal question', at a date convenient to the president.73 Debates at area councils were 'rarely assertive', so any exception to this rule could not be lightly ignored given that they represented a 'substantial body of opinion.' 74 Derby took the precaution of not calling the special meeting until after Baldwin convened a national party meeting on 30 October to address the crisis. In advance of that crucial

69 LCDA Annual Meeting, 26 October 1929, ARE/3/1/1.

70 LCDA Quarterly Meeting, 18 January 1930, ARE/3/1/1.

71 Clitheroe CA Annual General Meeting, 15 February 1930, DDX 800/1/2; Prestwich CA committee, 27 February 1930, 27 March 1930, 24 April 1930, 26 June 1930, PLC 1/2; LCDA Quarterly Meeting, 12 April 1930,

ARE/3/1/1; Neville Chamberlain to Derby, 27 June 1930, 920 DER (17) 31/5.

72 LCDA Annual Meeting, 19 July 1930, ARE/3/1/1.

73 LCDA Meeting, 4 October 1930, ARE/3/1/1.

74 Ball, Portrait of a Party, 244. 
convocation, Derby confided to Baldwin that he no longer had confidence in his leadership, and that he would not speak in his favour at the party meeting or even attend.75

Baldwin managed to survive the October meeting by successfully asking delegates to allow him a 'free hand' in pursuing a recent offer from the Canadians for reciprocity in tariff policy. The Lancashire division's special council meeting assembled four days later. Presiding over 289 delegates, Derby's restored confidence in Baldwin was evident in his invitation to Sykes that he propose a motion endorsing Baldwin's 'free hand' policy. An amendment was also proposed, by Mrs Phillips Brocklehurst and Mrs Hornyold, urging Baldwin 'when framing the details of his fiscal policy to take counsel with some of the leading younger members of the Party', but Derby successfully made 'a strong appeal for a unanimous vote in favour of the policy as laid down by Mr Baldwin'.76 For Lancashire's area council, if not the wider party, Baldwin's leadership was no longer a pressing matter.77 The following year, in September 1931, after the resounding election victory of the Conservative-dominated National Government, most Conservatives looked forward to a new imperial trade agreement that might heal internal divisions over tariffs and provide a positive economic policy. A motion to this effect at the 1931 party conference was proposed by delegates representing Lancashire, an especially symbolic gesture given that it was held at Birmingham. 78

\section{Indian Constitutional Reform}

Lancashire Conservatives placed their hopes for economic recovery in an imperial trade agreement and did not express any concern about contemporary developments towards extending Indian responsible government, despite the considerable attention given to India in parliament and the press.79 The area council's minute books are silent about the 1927

\footnotetext{
75 Middlemas and Barnes, Baldwin, 578-579.

76 LCDA Special Meeting, 15 November 1930, ARE/3/1/1.

77 Derby to White, 12 October 1931, 11 January 1932, 920 DER (17) 6/34.

78 LCDA Meeting, 5 September 1931, ARE/3/1/1.

79 St John, 'Writing to the Defence of Empire'.
} 
parliamentary commission established to review the provisions of the 1919 India Act, Lord Irwin's vice-regal declaration on dominion status in 1929, and the first two 'round table' conferences convened at London between November 1930 and December 1931. Even Winston Churchill, at a by-election campaign in East Toxteth in February 1931, made only the 'briefest' reference to India.80 Indeed, it was not until the conclusion of the third round table conference, in December 1932, that delegates to the area council linked Indian constitutional reform with cotton exports. At its quarterly meeting on 14 January 1933, the India Secretary was reproached by a delegate for not mentioning the cotton trade at the concluding session of the round table conference. Joseph Nall, MP for Manchester Hulme, persuaded the meeting to avoid personal criticism of Hoare, and support instead a resolution which 'earnestly [begged] the Government to take every possible step, both prior to and during the coming sittings of the Select Committee, to safe-guard the Lancashire Cotton Trade by assuring for it a fair and reasonable chance to compete in the Indian Market.' 81

The area council's belated interest in Indian responsible government was not unusual. Grassroots Conservatives tended to focus on immediate issues, so it was not until the publication of the India white paper in March 1933 that most associations considered the matter. Lancashire therefore gave its reaction sooner than most. This can be explained by the launch of the Cotton Trade League on the day prior to the area council's January meeting. This new organisation called on the government to tackle Lancashire's dwindling export trade to India and other colonial markets, 'against Japanese and other foreign competition.' According to the press, it was founded and led by the Conservative MP for Manchester Platting, Alan Chorlton, along with his brother, Alfred Chorlton, and Astley Bell of Preston. 82 The MP for Manchester Gorton, Shackleton Bailey, was also involved. In contrast to its precursor, the Cotton Trade Tariff Reform Association, founded in 1910, the commitment of the Cotton Trade League to tariffs

80 Thomas White to Derby, 6 February 1931, 25 June 1931, 17 September 1931, 920 DER (17) 6/33; Derby to White, 19 September 1931, 920 DER (17) 6/34.

81 LCDA Minutes, 1932-65, Quarterly Meeting, 14 January 1933, ARE/3/1/2.

82 Muldoon, 'Unholy Row', 97; The Times, 20 Sept. 1937, 14. 
was more than 'tactical', and its object was less out of step with local Conservative feeling. 83 The league mobilised fifty or so manufacturers to circumvent the more cautious approach of the Manchester Chamber of Commerce.84 It was deaf to those in the industry who argued for its rationalisation, in part because it remained Britain's largest single exporter until the end of the decade. 85 The coincidence of aims between the new league and the diehards' India Defence League (IDL) inevitably led to some cooperation, but it was never a diehard vehicle. Prior to the league's formation, Chorlton and Bailey had failed to support a diehard amendment on India brought before the House of Commons in December 1931, despite a recent rise in India's import duty.86 Both men represented seats won from Labour at the 1931 general election, and their concern for local opinion is evident in their reactions to the IDL following Churchill's failed attempt in 1934 to expose Derby and Hoare's dealings with the Manchester Chamber of Commerce; Chorlton pulled out of chairing Churchill's 26 June rally at Manchester's Free Trade Hall, and Bailey afterwards condemned Churchill's attacks on Derby and 'methods of controversy'.87

At the Cotton Trade League's founding meeting at Manchester, Chorlton read a letter from Mr F. Holroyd, ex-president of the Master Cotton Spinners' Federation, which referred to the failure of the 'London Press' to do justice to Lancashire, describing the situation as 'desperate' and calling for 'desperate action.' 88 The new league met with a government minister, Sir Philip Cunliffe-Lister, but it soon after criticised parliament for being 'indifferent' to their plight. 89 From June 1933 the league highlighted 'the labour conditions in Japanese mills, the low wages, and the long working hours, which give mill-owners in Japan an unfair advantage over their Lancashire competitors', and claimed 'that no collective agreements are in operation in the

\footnotetext{
83 Dutton, 'Lancashire', 139.

84 Chatterji, Trade, 376; Muldoon, 'Unholy Row, 97.

${ }_{85}$ Chatterji, Trade, 9, 12.

86 House of Commons Debates, 3 December 1931, vol. 260, cols 1287-1413; Chatterji, Trade, 350.

87 Bridge, Holding India, 131; The Times, 28 June 1934, 15.

88 The Times, 14 Jan. 1933, 12.

89 The Times, 31 Jan. 1933, 10; 12 April 1933, 9.
} 
Japanese cotton industry.'90 The league attacked the President of the Board of Trade, Walter Runciman, for suggesting that Lancashire cotton should 'look to itself rather than to the Government for help in its present distresses'.91 It called for quotas 'to prevent the systematic undercutting by Eastern nations of the selling prices of British goods produced under British standards of living', and demanded the formal separation of Burma and India when it became clear that Lancashire's exports to Burma were subject to Indian tariffs. 92 The Manchester Chamber of Commerce responded initially to the league by adopting a more confrontational attitude to the India Office. Over time, however, moderate minded members prevailed, conscious that cooperation rather than confrontation with Indian cotton manufacturers was more likely to help their industry survive. 93 It was their behind-the-scenes collaboration with Hoare and Derby that led Churchill on his doomed attempt to expose a breach of parliamentary privilege.

Lancashire's relatively early intervention in Conservative debates about Indian reform helps to account for its prominence at the party's Central Council meetings in February and June 1933. At the first, which was convened a fortnight prior to the publication of the India white paper, a motion in favour of safeguarding the cotton trade, proposed by Mrs Assheton on behalf of the Lancashire division, received support from the 'overwhelming majority' in attendance.94 At the June Central Council, Lancashire's delegates demonstrated their loyalty to Baldwin by amending a diehard resolution intended to criticise the National Government to one that endorsed the establishment of a joint select committee (JSC) of MPs and peers. 95 In effect, it obliged Conservatives to remain silent on Indian reform until the JSC published its findings. Control of the reform process was thereby placed in the hands of the India Secretary; he further bound Lancashire to the process by inviting Nall and Derby to sit on the JSC. The silence imposed on

\footnotetext{
90 The Times, 29 June 1933, 11.

91 The Times, 30 Jan. 1934, 16. See also, The Times, 10 March 1934, 14; 21 March 1934, 26.

92 The Times, 17 April 1934, 16; 9 May 1934, 8; 21 May 1935, 18.

${ }_{93}$ Chatterji, Trade, 18-19, 381-386.

94 The Times, 1 Mar. 1933, 9, 15.

95 The Times, 26 June 1933, 14; 29 June 1933, 14.
} 
Conservatives underscored the utility of the Cotton Trade League, and prompted other bodies, such as Oldham Chamber of commerce, to actively campaign on the issue.96 Despite these alternative outlets, the capacity of Lancashire's area council to remain silent dissipated within two months, prompted by the attendance at their April meeting of R.A.B. Butler, Under Secretary of State for India.97 Bailey informed the minister of his disagreement 'with many of the proposals contained in the White Paper', and accused the JSC of being biased in favour of the government's position. When Butler was called upon to speak, he was able to do so for only 'a short time' as delegates assailed him with questions. Thomas White, leader of party in Liverpool, managed to steer the meeting away from an outright attack on the government by proposing a resolution that welcomed the formation of the JSC.98 Writing afterwards to Derby, White confided that 'we should have gone down had there been more men present ... the women seemed to be in the majority and secured the passage of the resolution. Also there seemed to be quite a number present who did not trouble to vote.'99 He anticipated that a propaganda campaign might dispel concerns and change views about India. Derby also believed that a majority were against the government's policy, but he hoped to bring his personal authority to bear at the next area council by accounting for his membership of the JSC. 100

Derby's confidence proved to be misguided; the area council was too large to yield easily to the contrary opinions of its leading officers. In the more manageably sized constituency associations, MPs and chairmen enjoyed greater success in securing the cooperation of their membership, albeit with some dissentients. 101 It appears that only the member for Liverpool Walton, Reginald Purbrick, failed to carry the majority of his association in opposing the white

\footnotetext{
96 J.L. McCarthy [Secretary, Liverpool Chamber of Commerce] to Derby, 29 April 1933, 920 DER (17)/1/12. 97 White to Derby, 29 April 1933, 920 DER (17) 6/33.

98 LCDA Quarterly Meeting, 29 April 1933, ARE/3/1/2.

99 White to Derby, 2 May 1933, 920 DER (17)/1/12.

100 Derby to White, 1 May 1933, 920 DER (17) 6/34; White to Derby, 29 June 1933, 920 DER (17) 6/33; Derby to White, 30 June 1933, 920 DER (17) 6/34; LCDA Annual Meeting, 8 July 1933, ARE/3/1/2. 101 Waterloo Conservative Association Annual Meeting, 31 May 1935, Lancashire Archives, DDX 806/1/4.
} 
paper. 102 The MP for Clitheroe, Sir William Brass, was more typical. A former parliamentary private secretary to Neville Chamberlain and Leopold Amery, Brass was a strong supporter of the government on India despite protests from local mill workers. 103 The Scot, Sir Nairne Stewart Sandeman, likewise had the support of his association, Middleton and Prestwich, in opposing the white paper. The association was even willing to support his working alongside the IDL. 104 He overreached himself, however, when he encouraged his agent, Mr Potts, to act as agent for Randolph Churchill at Wavertree. Stewart Sandeman survived a motion of confidence, but the experience led him to consider standing down at the next general election. 105

Derby's hopes of giving a steer to the area council were dashed by its adoption of resolutions that echoed the pronouncements of the Cotton Trade League; these commanded large majorities, which suggests that White too was mistaken in assuming that women were less likely to express dissent. At a council meeting on 14 October 1933, the MP for Accrington, Henry Procter, and the MP for Macclesfield, John Remer, put forward a resolution urging the government 'in the interests of British industry, especially the Lancashire Cotton Industry, to take effective measures to combat unfair Japanese competition in Home and Empire markets.'106 This referred to the Japanese government's demand for tariff concessions from India in return for ending its boycott of Indian-grown raw cotton. As the British government did not want to antagonise cotton manufacturers in Lancashire or India, ministers concocted a plan to purchase Indian raw cotton to render the Japanese boycott ineffective, and kept it secret to avoid other industries expecting similar treatment. With the exception of Derby, Lancashire Conservatives were oblivious to these secret manoeuvrings, and the Cotton Trade League remained gloomy 
about the future of the industry.107 The MP for Nelson and Colne, Linton Thorp, along with Remer, brought resolutions before the May 1934 council meeting, condemning 'the menace of Japanese competition in the Textile Areas'. The Secretary at the Department of Overseas Trade, John Colville, was present, and heard another resolution demanding government action to protect Lancashire's trade with West Africa.108

In the meantime, Winston Churchill made his allegations about Hoare, Derby and the Manchester Chamber of Commerce, further delaying the business of the JSC. If this obliged Chorlton and Bailey to publicly distance themselves from Churchill and the IDL, it nevertheless helped to keep Lancashire a prominent feature in party debates about India, and is likely to have exacerbated the frustration of ordinary Conservatives with having to remain silent until the publication of the JSC's report. This was the subject of a diehard motion brought before the party's Central Council in October 1934, which the leadership won by a narrow margin, 543 to 520.109 A week later, the Lancashire division's area council discussed imperial trade at length, and agreed a set of resolutions, proposed by Remer and Thorp, which called on the government:

(1) To deal effectively in the Home, Dominion and Colonial Markets with competition from foreign countries where wages are lower and hours of employment are longer than those existing in Lancashire and Cheshire, or where subsidies are being given to our foreign competitors either directly or by depreciated currency. (2) To extend the spirit of Ottawa by securing arrangements for reciprocal trade with the Colonies and Dominions ... (3) To make no Trade Agreements with foreign countries which do not, as one of the first considerations, make arrangements for favourable terms for textiles and that before any such Treaties are negotiated, the Most Favoured Nation Clause in all Treaties with foreign countries

\footnotetext{
107 Muldoon, 'Unholy Row', p. 103; The Times, 5 Jan. 1934, 11.

108 LCDA Quarterly Meeting, 5 May 1934, ARE/3/1/2.

109 The Times, 5 Oct. 1934, 14.
} 
should be denounced. (4) That no changes in any Empire Constitution shall be made without adequate safeguards being secured for export trade in textiles.110

Three MPs at the meeting spoke in opposition to the resolution, and many more continued to support the party leadership's handling of Indian reform.111 But the determined opposition of a majority of council delegates was palpable. Hoare's continued efforts to secure a favourable hearing for Lancashire in India eventually secured a modest promise of concessions ahead of the India bill and assurances of a subsequent review of tariffs. 112 This helped to placate wider concern in the party, but it was significantly less successful in Lancashire.113 The Cotton Trade League depicted Hoare's achievement as 'exchanging concessions in immediate operations for vague and unsubstantial promises to be fulfilled perhaps in the distant future.' 114 The league also attacked the JSC's report following its publication in December 1934, for doing nothing to curtail the role of Indian politicians in setting tariffs.115 Derby privately expressed his belief that at least one local diehard MP had become 'half hearted' in his opposition, but in declining a Central Office request to promote the JSC report, the earl shrewdly avoided testing the resolve of his area council.116 On 12 January 1935, weeks before the introduction of the India bill, Bailey and Remer proposed yet another censorious resolution at the council which secured a 'very large majority':

That this Meeting ... regrets that so little has been done towards carrying out the Resolution on Textiles passed by this Council at its last Meeting, and in view of the

\footnotetext{
110 LCDA Quarterly Meeting, 13 October 1934, ARE/3/1/2.

111 Anthony Crossley (Oldham); Sir John Sandeman Allen (Liverpool West Derby); and J.S. Allen (Birkenhead West). 
continued unfair competition, particularly Japanese competition, it is ... essential for a Cabinet Minister to visit Lancashire and Cheshire for the purpose of meeting Textile manufacturers and obtaining accurate knowledge of this problem, which so vitally affects the welfare of employers and employed in the Textile Industry.117

The Cotton Trade League inevitably condemned the India bill for not making 'the least response to the complaints of Lancashire.'118 Bailey, Remer, Chorlton, Nall, Thorp, and seven other Lancashire MPs, helped to make up the 84 Conservatives who on 11 February voted against the second reading of the bill, one of the party's largest backbench rebellions in the twentieth century.119 It was a sizeable display of dissent, but not sufficient to damage the National Government's large majority.

The quarterly meeting of the area council on 12 January was the last occasion on which it discussed the India question. It had no opportunity to comment on the sudden decision of Randolph Churchill, a week later, to stand against the official party candidate at the Liverpool Wavertree by-election. His decision was the latest attempt by diehard Conservatives to adhere Lancashire to their campaign. This alliance of interests was far from straightforward. Before the Great War, leading diehard MPs such as Henry Page Croft were pitted against Lancashire on the fiscal question. Lancashire's subsequent shift to supporting an imperial trade agreement unavoidably brought some activists into contact with Page Croft and his Empire Industries Association, but many no doubt remained wary of Conservatives who questioned or undermined the work of the National Government, especially given the party's recovery in Lancashire at the 1931 general election. 120 Chorlton and Bailey's concerns about the IDL's campaign in Lancashire

117 LCDA Meeting, 12 January 1935, ARE/3/1/2.

118 The Times, 23 March 1935, 14.

119 Seventy nine Conservative MPs voted against, in addition 3 paired, and 2 served as tellers, The Times, 12 Feb. 1935, 9; The Times, 13 Feb. 1935, 12. The seven other Lancashire MPs were Frederick Wolfe Astbury (Salford West); John Broadbent (Ashton-under-Lyne); C.C. Erskine-Bolst, (Blackpool); Edward Lascelles Fleming (Withington); Albert G. Fuller, (Ardwick); John Lees-Jones (Manchester Blackley); Reginald Purbrick (Liverpool Walton); and Nairne Stewart Sandeman (Middletown and Prestwich).

120 Prestwich CA committee, 24 September 1931, PLC 1/2; LCDA Annual Meeting, 7 July 1934, ARE/3/1/2. 
are noted above. There is little evidence to suggest that other Lancashire MPs and opponents of the India bill shared the diehards' wider critique of Indian self-government; of the five who voted against Indian self-government in 1931, only Remer was a confirmed diehard.121 The diehards' arguments against extending responsible government in India frequently highlighted the supposed incompatibility of its people and culture with democracy. Especial prominence was given to incidents of 'terrorism' as well as the neglect of low-caste untouchables and religious minorities by ‘Brahman’ politicians. 122 The minutes of the Lancashire division's area council make no reference to these arguments; its concerns were confined to trade with India. If anything, its debates about India acknowledged that the government had restored law and order. This narrow focus was consistent with the longstanding priorities of Lancashire Conservatives, including, possibly, concern for the opinion of women mill workers. They had come out to cheer Mohandas Gandhi when he visited several Lancashire mill towns in September 1931, to explain his boycott of Lancashire cotton, and there seemed little profit locally in attacking the man or his cause. 123

For their part, diehards had no difficulty highlighting Lancashire's industrial decline, even if they were not fully cognisant of the economic details or knowledgeable about the county's political culture.124 In May 1933, Winston Churchill and Lord Lloyd addressed a meeting of the India Trade Preservation Society, a body which claimed to be 'closely associated' with the Cotton Trade League, at Manchester's Free Trade Hall, and Churchill returned to the venue in June 1934, at the IDL rally which prompted Chorlton and Bailey to distance themselves from the diehards. 125 If prominent Lancashire Conservatives were wary of openly identifying with the diehards, the evidence suggests that sections of the grassroots were more cooperative.

\footnotetext{
121 The others were John Broadbent (Ashton-under-Lyne), Purbrick (Liverpool Walton), Stewart Sandeman (Middletown and Prestwich) and Nall. Remer's business background led him to complain about the lack of ministers with business experience. The centre and left of the parliamentary party referred to him and other right-wing businessmen MPs pejoratively as the 'Forty Thieves', Ball, Portrait of a Party, 314, 332-333.

122 Fleming, 'Diehard Conservatism', 352-355.

123 Thompson, Empire Strikes Backe?, 77-78.

124 The Times, 27 June 1934, 9.

125 The Times, 13 May 1933, 7; 28 June 1934, 15.
} 
Conservatives in Manchester, for example, covertly supplied the IDL with the names and addresses of party members, and the city's Conservative Club publicly called on Page Croft to offer advice to the Cotton Trade League on the minimum safeguards required in the India bill.126 The diehard MP's response was typically blunt, that safeguards must ensure that 'British and Indian trade shall be upon a mutual reciprocal basis in perpetuity', adding that any tariffs on each other's products must be half of those charged on 'foreign' goods. ${ }_{127}$ The diehard peer, Lord Sydenham, was equally defiant in warning Lancashire that it had 'nothing to hope from the socalled "Liberals" led by Brahmins, and belonging in the words of an Indian, to a class of "educated Indians as intolerant and relentless as any known in history." 128 A significantly milder version of Sydenham's outlook is found in the Cotton Trade League's claim that 'the welfare of the great mass of the inhabitants of India is being sacrificed to the advantage of the relatively small body operating the cotton industry there', but it was a minor theme for the league, and one not picked up by the Lancashire divisional association. 129

\section{The Wavertree By-Election}

The Liverpool Wavertree by-election was triggered in December 1934 by the elevation of the sitting Conservative MP, Ronald Nall-Cain, to the House of Lords. Delays in issuing a writ for the by-election, and in selecting a Conservative candidate, provided an opportunity for speculation on whether or not a national figure might emerge to contest the seat.130 Randolph Churchill's name was touted as a possibility, though doubt was expressed given his father's position on India.131 A meeting of the constituency association in late December chose the relatively unknown figure of James Platt, a local cotton merchant, and the decision was reported

126 George Whittaker [secretary, Exchange Ward Conservative Association] to Derby, 1 July 1934, 920 DER (17) $16 / 3$.

127 The Times, 25 April 1934, 25.

128 Lord Sydenham, 'The Effect of Indian Reform on Lancashire Trade', Indian Empire Review, vol. 2, no. 4 (April 1933), $22-25$.

129 The Times, 2 Oct. 1934, 11. Even criticism of non-economic aspects of the white paper were rare, see, Prestwich CA General Purposes Committee, 20 June 1933, PLC 1/2.

130 The Times, 6 Dec. 1934, 8.

131 The Times, 24 Dec. 1934, 7; 29 Dec. 1934, 5. 
as an expression of association's eagerness 'to keep Wavertree true to the Government.' 132 A Conservative hold was predicted, but with 'a greatly reduced majority'.133 Over the weekend of 20 January, however, news emerged of Churchill's decision to stand, on the grounds that he was 'not satisfied that Mr Platt is prepared to fight for the vital requirements of Lancashire trade.' 134 Churchill's announcement was accompanied by news that White, the Conservative leader in Liverpool, intended to issue a writ for libel against him for derogatory comments made in the press. 135 The theatricality of Churchill's entry to the contest continued through to polling a fortnight later, considerably heightening national interest in what was a reasonably safe Conservative seat. 136

Churchill's announcement initially caused 'amusement rather than resentment' amongst local Conservatives, and it was suggested that he could only take a 'negligible' number of votes from Platt.137 Liverpool's Conservative association, after all, had on several occasions demonstrated its support for the government's India policy.138 The Times' correspondent claimed that Platt knew Wavertree better than Churchill, and that 'it was impossible to get the electors of any Liverpool division to become excited over the manufacturing and exporting side of the cotton trade', as they were more concerned with the importation of cotton. 139 Churchill's campaign sought to counter this by cultivating local unease about Westminster's neglect of the northwest, and Liverpool in particular, alongside more typical diehard preoccupations with rearmament and party 'renewal'. At his first public meeting at Wavertree, Churchill declared that he had 'butted in' as he not been invited by a deputation: 'deputations do not wait upon young men, certainly not deputations from Lancashire. They wait upon Sir Samuel Hoare.' He went on to claim that Lancashire's voice had been silenced and blamed its representatives:

132 The Times, 29 Dec., 5; 30 Dec. 1934, 3.

133 The Times, 7 Jan. 1935, 18; 18 Jan. 1935, 9.

134 The Times, 21 Jan. 1935, 14.

135 Yorkshire Post, 22 Jan. 1935, 7.

136 Lawrence, Electing Our Masters, 3-4.

137 The Times, 21 Jan. 1935, 14.

138 Secretary of Liverpool Constitutional Association to Derby, 26 June 1933, 920 DER (17) 6/33; Derby to White, 27 June 1933, 920 DER (17) 6/34; White to Derby, 1 December 1934, 920 DER (17) 6/33.

139 The Times, 21 Jan. 1935, 14. 
I do not think much of your Lancashire MPs. They are a pretty gormless crowd, and would rather get a smile from Mr Baldwin than stand up for Lancashire. As soon as your members get to London they are dazzled by the big lights (Laughter). They are so impressed by meeting a few 'nobs' that they very quickly forget the tragic conditions in the county they have left.140

Churchill's opening speech promised a 'lively' contest, according to one reporter, though it added disparagingly that he 'seems to be at the stage of exuberance when impertinence is mistaken for ability.' 141 The Daily Express reported that the excitement produced by Churchill's entry was evident in 'packed' political meetings and reduced ticket receipts for local cinemas.142 The Beaverbrook organ supported Churchill by puffing his credentials as an 'empire free trader'. It mocked Platt's election posters for claiming that he was the 'National' candidate, and for subsequently ordering new posters on which he was labelled a 'National Conservative'. 143 'The Express also backed Churchill's claim that he was the real Conservative, and argued that Platt was 'standing as the supporter of a Socialist Prime Minister.' 144 To rebut the charge of knowing little about the area, Churchill informed his first meeting at Wavertree that he had 'spent the last summer touring Lancashire, speaking on behalf of a policy of fair play in India. Everywhere he found support but nothing happened.' 145

The Times' commitment to Indian constitutional reform accounts for its partisan coverage of the campaign. ${ }_{146}$ Churchill's speeches were seldom reprinted or referred to by the newspaper, but as his candidacy evolved from a joke into a serious threat to Conservative victory, The Times was

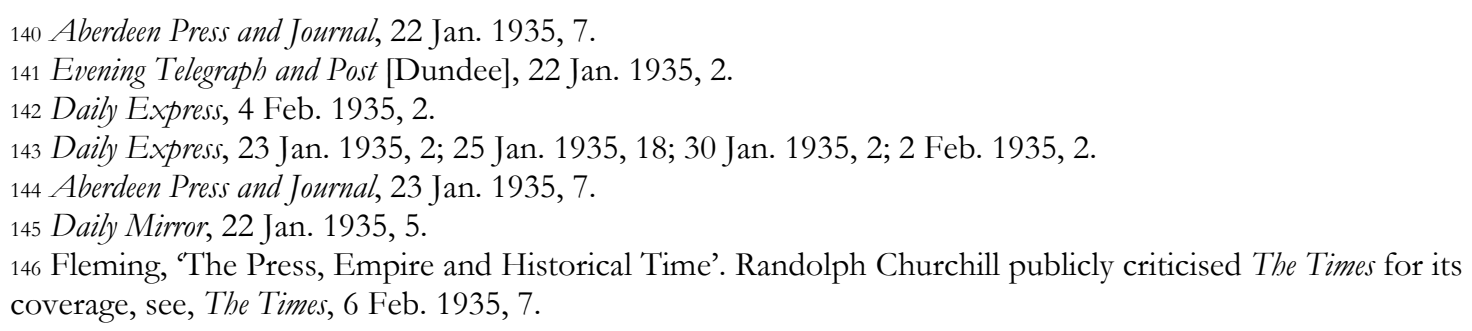


obliged to qualify or rethink some of its assertions. It initially attributed support for Churchill to general disgruntlement with the government, rather than 'the Indian question, so far as it bears on the Lancashire cotton industry, for interest in that is but tepid.' 147 This was an overstatement, even for Liverpool, for the port city 'was still hostage to Lancashire's falling capacity to export and to the level of world trade.'148 The Times subsequently acknowledged that Churchill had 'forced the question of Lancashire's trade interests in India to the forefront among platform topics'. This obliged Platt to reassure Conservatives that although he supported the India bill, he reserved the right to oppose any clause that he regarded as not safeguarding the interests of Lancashire.149 The Times attributed attendances at Churchill's platforms to popular curiosity with the bearer of a great name, his 'tirades' were contrasted with the 'slow and deliberate' speech of Platt, and 'enthusiastic' support for Churchill at a meeting of Liverpool businessmen was glossed over with suggestions of doubt among their number. It was obliged to concede that Churchill had attracted the support of some leading Lancashire figures, including Nall, but the newspaper suggested that the rank and file had 'not been led away from loyalty to the party'.150 The Times could not disguise the excitement aroused by Churchill's candidacy, or the fact that it obliged Platt to defend an Indian policy that appeared to offer minor concessions to Lancashire trade.151 Little wonder it declined to dwell the decision of the Indian Legislative Assembly, in the run up to the poll, to reject an attempt to extend the Ottawa principle to British imports.152 This decision led a number of Conservative MPs representing Lancashire to publicly indicate their concerns with the trade provisions of the India bill; that they did so on the eve of the by-election suggests that this was as much a response to Wavertree as New Delhi.153

147 The Times, 22 Jan. 1935, 9.

148 Baines, 'Merseyside in the British Economy', 60.

149 The Times, 23 Jan. 1935, 14. For similar reassessment of Churchill's intervention see, Henry Channon, diary, 24 January 1935, in Rhodes James (ed.), Chips, 23.

150 The Times, 4 Feb. 1935, 14. Other papers reported Churchill's high level local support much earlier, see, Aberdeen Press and Journal, 20 Jan. 1935, 7.

151 The Times, 24 Jan. 1935, 14; 25 Jan. 1935, 16; 30 Jan. 1935, 14; 1 Feb. 1935, 8; 2 Feb. 1935, 14.

152 Chatterii, Trade, 399-401; Yorkshire Post, 5 Feb. 1935, 11

153 Yorksbire Post, 5 Feb. 1935, 11. 
In contrast to The Times, the Daily Mail, Daily Express and the Daily Mirror supported

Churchill's intervention. The backing of the Mirror, in particular, was significant as it had a predominantly female working-class readership, and its coverage drew attention to Churchill's support among local women.154 An early report claimed that 'the only candidate who is accessible at all times seems to be Mr Randolph Churchill', and that the 'electors believe that the real fight is between Mr Churchill and Councillor [J.J.] Cleary, the Socialist.' 155 The Mirror celebrated Churchill's power over large and unruly audiences, claimed that an opinion poll of working men revealed that a majority would vote for Churchill, and reported enthusiastically on the ' 8,000 ' strong meeting held on the eve of the poll.156 Its reportage highlights Churchill's capacity to tailor his appeal to local working-class electors; through advocating slum clearance, rehousing, and the freer use of national credit to relieve unemployment; and also to the increasing numbers of unemployed middle-class professionals created by the relocation of shipping companies from Liverpool to Southampton.157

Winston Churchill reluctantly supported Randolph's decision to stand, as did many diehard MPs and peers. To an audience at Bristol, the father depicted his son as a 23 year old who had brought forth all the 'wealth' and 'wire pulling' the government could muster.158 Perhaps acknowledging that Randolph's youth diminished his decision in the eyes of many, Winston tried to make it a virtue, warning that 'if the patriotic youth of Britain find that their path is everywhere barred by the older generation', then the Conservative party will have 'cut itself off from the harvest of the future.'159 Having initially disapproved in private, Winston's public defence of Randolph developed quickly into a wider attack on the government that echoed the election speeches of his son. At one meeting, Winston went so far as to claim that the National

154 Koss, Rise and Fall of the Political Press, 954; Daily Mirror, 25 Jan. 1935, 2; 26 Jan. 1935, 2. The endorsement of the Mirror was not entirely unexpected given that Churchill had previously worked for the Rothermere press, see, Swift, 'Randolph Churchill and the General Election in Preston', 126.

155 Daily Mirror, 24 Jan. 1935, 2.

156 Daily Mirror, 2 Feb. 1935, 4; 4 Feb. 1935, 4; 5 Feb. 1935, 4; 6 Feb. 1935, 2.

157 Daily Mirror, 30 Jan. 1935, 4; Swift, 'Randolph Churchill and the General Election in Preston', 123; Baines,

'Merseyside in the British Economy', 61-62.

158 The Times, 26 Jan. 1935, 13, 14.

159 Aberdeen Press and Journal, 26 Jan. 1935, 7. 
Government could not be 'national' as it was headed by an 'International Socialist' and 'opposed by two out of three of the official great parties in this country.' 160 Filial loyalty is evident also in Randolph's platform complaints about the power of the 'caucus', both nationally and in Liverpool.161 This echoed his grandfather's preoccupation with the leadership's control over the party machine, and was employed at Wavertree to claim that party bosses had marginalised local opinion. 162

Senior Conservatives regarded the diehards' support for an independent Conservative as an act of 'aggression'; a charge seemingly vindicated by Lord Carson's public endorsement of Churchill, which called for more 'fighting men' in parliament to save the empire, and Lord Lloyd's admission that he did 'not care' that critics accused him of disloyalty.163 Such grandstanding, however, ultimately weakened the diehard case at Westminster, for it allowed Baldwin, along with other senior figures in the government and party, to claim the moral high ground. 164 Numerous letters and speeches were issued regretting the divisions caused by Churchill's candidacy, and claiming also that the question was one of confidence in the work carried out by the National Government.165 Senior party figures, including Anthony Eden, visited Wavertree to speak on Platt's behalf; Sir John Simon encouraged National Liberals to vote for Platt rather than the Liberal candidate, T.A. Morris. 166 The odium poured on the IDL for its intervention at Wavertree led two MPs, A.W. Goodman and William Craven-Ellis, to publicly resign from the organisation. 167 One journalist wondered if the 'internecine' warfare in the Conservative party over India would lead to 'Wavertrees throughout the country', with rival Conservative candidates standing at the next general election.168

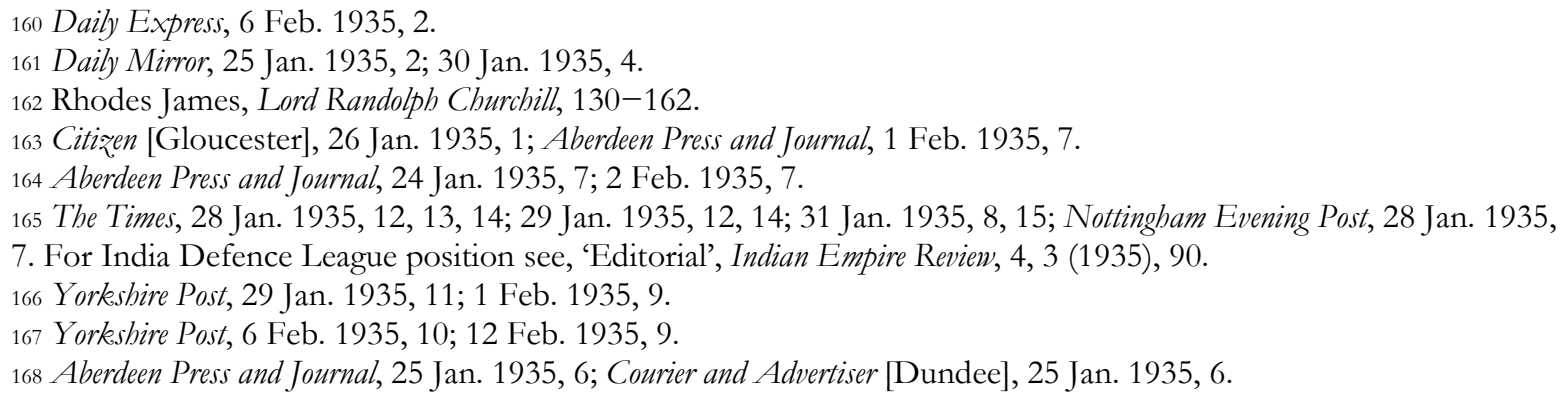


Following the poll held on 6 February, it was announced that Churchill had secured 10,575 votes, three thousand less than Platt. Inevitably, Churchill's achievement was overshadowed by the loss of the seat to Cleary. Almost half of Wavertree's Conservative voters were prepared to ignore the official candidate, but the evidence is ambiguous about attitudes of party activists in Lancashire. The area council's schedule of quarterly meetings meant that it did not convene during the contest. This avoided a potentially uncomfortable scrutiny of its professions of loyalty to the party leader given that its resolutions on India were a far cry from Platt's cautious approach to the issue. Nor did it revisit the India question after Wavertree; the bill's progress through parliament meant that this would achieve little, other than expose and heighten tensions locally. Outside of Liverpool, the opinion of Conservatives is difficult to delineate. In contrast to the area council, the Lancashire division's Women's Advisory Council was prepared to discuss Wavertree, but a motion condemning Churchill led delegates from Bury to declare that their local association was not in agreement with the resolution.169 The concern of some Prestwich Conservatives about the role of their agent in Wavertree is noted above, as is Stewart Sandeman's deliberation about standing down at the 1935 general election. 170 He was not unusual in thinking about retiring from politics; Lancashire had a disproportionately high number of MPs follow through. 171 As the chairman of the Manchester Conservative Association informed Derby, the divisions experienced locally over India would take a while to 'forget'. 172

The declarations of Liverpool Conservatives, when they were forthcoming, tended to support Platt.173 He received the public endorsement of eight out of nine Liverpool MPs, the city's Junior Conservatives, the Liverpool Women's Unionist Federation, and the former MP, Nall-Cain, now

169 NAWAC Meeting, 6 March 1935, ARE/3/11/1.

170 Prestwich CA Annual General Meeting, 16 March 1935, PLC 1/2.

17116 out of the 57 Conservative retirements represented constituencies in Lancashire and Cheshire, see, Ball, Portrait of a Party, 317.

172 J.H. Swales to Derby, 10 July 1935, 920 DER (17) 16/3.

173 Some declined to discuss Wavertree, see, Waterloo Women's Conservative Association Minutes, Lancashire Archives, DDX 806/2/1. 
Lord Brockett. 174 Only Purbrick declined to support the official candidate, and without the support of his constituency association.175 Against this formidable list of Liverpool Conservatives, Churchill could muster only Archibald Salvidge, son and namesake of the architect of Conservative dominance in Liverpool; though covert assistance with his campaign was more forthcoming from local activists.176 After the declaration of the by-election result, Churchill announced that he intended to remain a figure in Liverpool politics. But his continued attacks on the city's 'caucus' failed to attract sufficient support.177 Derby was privately sympathetic to such criticisms. He therefore encouraged a rapprochement between White and Churchill, and helped to secure for the latter the party's candidacy in West Toxteth at the general election. 178

\section{Conclusion}

Lancashire not only debated and projected its own concerns about Indian constitutional reform, it was also the subject of rival Westminster campaigns to win over Conservatives in the county and across the country. Historiography has tended to focus on the latter at the expense of the former, a reflection of long held assumptions about the significance of local activism, particularly in the Conservative party. The intervention of Lancashire Conservatives was not spurred or shaped by the contending viewpoints in the parliamentary party. It was grounded in longstanding local anxiety about declining cotton exports to India, articulated also by the Manchester Chamber of Commerce, and less constructively by the Cotton Trade League. These

\footnotetext{
174 Sir John Sandeman Allen, Clement Brocklebank, Patrick Buchan-Hepburn, Frank Hornby, Robert Rankin, Sir John Rutherford, John Shute and Clyde Wilson, see, The Times, 5 Feb. 1935, 8; 26 Jan. 1935, 14; 29 Jan. 1935, 14; Yorkshire Post, 30 Jan. 1935, 7; 1 Feb. 1935, 9; Liverpool Women's Unionist Federation Executive Committee, 20 February 1935, $329 \mathrm{CON} / 1 / 8 / 2$.

175 Yorkshire Post, 5 Feb. 1935, 9; White to Derby, 22 April 1933, 920 DER (17) 6/33.

176 Daily Mirror, 1 Feb. 1935, 4; [Waterloo, Crosby, Seaforth, and Litherland] Women's Central Committee Meeting 15 March 1935, Annual General Meeting, 12 April 1935, Lancashire Archives, DDX 806/2/2.

177 Daily Mirror, 7 Feb. 1935, 1.

178 Liverpool Constitutional Association Board meeting, 29 April 1935, 329 CON/1/1/3; Derby to White, 26 August 1935, 29 August 1935, 22 September 1935, 10 October 1935, 920 DER (17) 6/34; White to Derby, 28 August 1935, 30 September 1935, 7 November 1935, 920 DER (17) 6/33; Daily Mirror, 23 February 1935, 5; 18 March 1935, 8; 1 May 1935, 7; Yorkshire Post, 9 May 1935, 5; 1 Aug. 1935, 7; 21 Aug. 1935, 7; The Times, 15 November 1935, 8. The Labour incumbent, Joseph Gibbins, won by over two thousand votes.
} 
concerns quickly came to occupy a central place in debates at Westminster and behind the scenes communications between the India Office and New Delhi. Lancashire Conservatives had hoped that the spirit of the Ottawa agreements, if not the letter, might reverse successive tariff increases imposed by India on Lancashire cotton. When these hopes appeared to be dashed, the Lancashire division's area council expected the government to include meaningful safeguards to protect cotton exports in legislation to extend Indian responsible government. It was a position rich with irony given the county's long opposition to protectionism. If this gradual reappraisal of the fiscal question brought Lancashire into step with wider party opinion, its rationale remained local. A history of defying the national party leadership in order to protect local interests, alongside efforts to accommodate workingmen and reach out to working women, leant Lancashire Conservatism a distinctive character. If it occasionally pitted the county against the rest of the party, it also assisted Conservative claims to represent one nation. For their part, Lancashire Conservatives were aware of the utility of the 'National' label in reviving their fortunes at the 1931 general election. The vulnerability of many of Lancashire seats, evident at the 1924 and 1929 general elections, underscored for both their reliance on the other. This was felt acutely by Lancashire's Conservative MPs, and helps to explain why a majority of their number remained loyal to the front bench over the India question.

Delegates to area council were further removed than MPs from the national party leadership and closer to supporters and the electorate. Their resolutions echoed the concerns raised by the Cotton Trade League, ignored those of the diehards, and continued to profess loyalty to the National Government. Front bench and diehard Conservatives alike believed it was worthwhile vying with each other to win over Lancashire Conservatives, even if the former knew that it could rely ultimately on the majority of the county's MPs to see its legislation through parliament. Churchill's intervention at Wavertree tried to cut through the resulting ambiguity, of loyalty to Baldwin and Hoare, but earnest criticism of the India white paper. It met with a mixture of responses locally, from enthusiasm, confusion, and silence, through to bitter 
resentment. His unexpectedly large poll, in a constituency not directly connected with cotton manufacturing, suggests that many Conservative voters were moved to make a statement to the incumbent government about Liverpool's economic woes. Whatever their motivations, Wavertree made an already tense situation in the party more difficult, especially in Lancashire, but it also brought into sharp focus the Conservatives' distinctive regional identity. This is most evident in its consistent emphasis on cotton exports, throughout the party crisis over India, which helped the credibility of Conservatives representing mill towns, most of whom held on to their seats at the 1935 general election despite the partial recovery of Labour. ${ }_{179}$ Conservatives even gained Darwen from the leader of the Liberal party and committed free trader, Sir Herbert Samuel. For two years the Lancashire division's area council and twelve of its MPs placed the concerns of the county above those of national party policy. If this proved to be uncomfortable for the front bench at Westminster, it also highlighted the responsiveness of Conservatism to local conditions, and the importance of this in maintaining electoral success even as local influence on central government was in decline.

\section{References}

Aubel, F.F.E. 'Welsh Conservatism 1885-1935: Five Studies in Adaptation', PhD Thesis, University of Wales, Lampeter (1994).

Baines, D.E. 'Merseyside in the British Economy: The 1930s and the Second World War', in Richard Lawton and Catherine M. Cunningham (eds), Merseyside: Social and Economic Studies. London: Prentice Hall, 1970: 58-71.

Ball, Stuart. Baldwin and the Conservative Party: The Crisis of 1929-1931. New Haven: Yale University Press, 1988.

179 Bailey (Gorton) and Chorlton (Platting) lost their seats to Labour. 
Ball, Stuart. 'The National and Regional Party Structure', in Stuart Ball and Anthony Seldon (eds), Conservative Century: The Conservative Party since 1900. Oxford: Oxford University Press, 1994, 169-220.

Ball, Stuart. Portrait of a Party: The Conservative Party in Britain 1918-1945. Oxford: Oxford University Press, 2013.

Bates, J.W.B. 'The Conservative Party in the Constituencies 1918-1939', DPhil Thesis, University of Oxford (1994).

Belchem, John. Irish, Catholic and Scouse: The History of the Liverpool Irish, 1800-1939. Liverpool: Liverpool University Press, 2007.

Blewett, Neal. The Peers, the Parties, and the People: The General Elections of 1910. London: Macmillan, 1972.

Bridge, Carl. Holding India to the Empire: The British Conservative Party and the 1935 Constitution. New Delhi: Sterling, 1986.

Cain, P.J., and A.G. Hopkins, British Imperialism, 1688-2000. 2nd edn, London: Longman, 2002.

Cawood, Ian. The Liberal Unionist Party: A History. London: I.B.Tauris, 2012.

Cannadine, David. The Decline and Fall of the British Aristocracy. London: Papermac, 1990.

Chatterji, Basudev. Trade, Tariffs and Empire: Lancashire and British Policy in India, 1919-1939. New Delhi: Oxford University Press, 1992.

Churchill, Randolph S. Lord Derby: 'King of Lancashire'. London, 1959.

Clarke, P.F. Lancashire and the New Liberalism. Cambridge: Cambridge University Press, 1971.

Cowman, Krista. Mrs Brown is a Man and a Brother: Women in Merseyside's Political Organisations, 1890-1920. Liverpool: Liverpool University Press, 2004.

Cowling, Maurice. The Impact of Labour 1920-1924: The Beginning of Modern British Politics. Cambridge: Cambridge University Press, 1971.

Crowson, N.J. Facing Fascism: The Conservative Party and the European Dictators, 1935-1940. London: Routledge, 1997. 
Davies, Sam, and Bob Morley, 'The Politics of Place: A Comparative Analysis of Electoral Politics in Four Lancashire Cotton Textile Towns, 1919-1939', Manchester Region History Review, 14 (2000): 63-78.

Dutton, David. 'Lancashire and the New Unionism: The Unionist Party and the Growth of Popular Politics 1906-1914', Transactions of the Historic Society of Lancashire and Cheshire, 130 (1981): 131-148.

Dutton, David. 'His Majesty's Loyal Opposition': The Unionist Party in Opposition 1905-1915. Liverpool: Liverpool University Press, 1992.

Dutton, David. “A Mad Hatter Contest from Beginning to End': Randolph Churchill and the Wavertree By-Election, February 1935', Transactions of the Historic Society of Lancashire and Cheshire, 142 (1993): 179-202.

Fleming, N.C. 'The Press, Empire and Historical Time: The Times and Indian Self-Government, $c$. 1911-1947', Media History, 16, no. 2 (2010): 183-198.

Fleming, N.C. 'Diehard Conservatism, Mass Democracy, and Indian Constitutional Reform, c. 1918-1935', Parliamentary History, 32, no. 2 (2013): 337-360.

Fleming, N.C. 'Diehard Conservatives and the Appeasement of Nazi Germany, 1935-1940', History, 100, no. 441 (2015): 412-435.

Ghosh, S.C. 'Decision-Making and Power in the British Conservative Party: A Case Study of the Indian Problem 1929-1934', Political Studies, 13, no. 2 (1965): 198-212.

Green, E.H.H. The Crisis of Conservatism: The Politics, Economics and Ideology of the British Conservative Party, 1880-1914. London: Routledge, 1995.

Harrison, Brian. Separate Spheres: The Opposition to Women's Suffrage in Britain. Rep. edn. London: Routledge, 2013.

Jarvis, David. 'Mrs Maggs and Betty: The Conservative Appeal to Women Voters in the 1920s', Twentieth Century British History, 5, no. 2 (1994): 129-152. 
Jarvis, David. 'The Conservative Party and the Politics of Gender, 1900-39', in Martin Francis and Ina Zweiniger-Bargielowska (eds), The Conservatives and British Society 1880-1990. Cardiff: University of Wales Press, 1996: 172-93.

Koss, Stephen. The Rise and Fall of the Political Press in Britain. London: Fontana, 1990.

Lawrence, Jon. Electing Our Masters: The Hustings in British Politics from Hogarth to Blair. Oxford University Press, 2009.

Lee, Alan J. 'Conservatism, Traditionalism and the British Working Class, 1880-1918', in David Martin (ed.), Ideology and the Labour Movement: Essays Presented to John Saville. London: Croom Helm, 1979: 84-102.

Middlemas, Keith, and John Barnes, Baldwin: A Biography. London: Weidenfeld and Nicolson, 1969.

Muldoon, Andrew. “An Unholy Row in Lancashire': The Textile Lobby, Conservative Politics, and Indian Policy, 1931-1935', Twentieth Century British History, 14, no. 2 (2003): 93-111.

Muldoon, Andrew. Empire, Politics and the Creation of the 1935 India Act: Last Act of the Raj. Aldershot: Ashgate, 2009.

Norton, Philip, and Arthur Aughey. Conservatives and Conservatism. London: Temple Smith, 1981.

Peele, Gillian. 'Revolt over India', in Chris Cook and Gillian Peele (eds), The Politics of Reappraisal, 1918-1939. London: Macmillan, 1975: 114-45.

Pelling, Henry. The Social Geography of British Elections 1885-1910. London: Macmillan, 1967.

Potter, Simon J. British Imperial History. London: Palgrave, 2015.

Pugh, Martin. The Tories and the People, 1880-1935. Oxford: Basil Blackwell, 1985.

Pugh, Martin. 'Lancashire, Cotton, and Indian Reform: Conservative Controversies in the 1930s', Twentieth Century British History, 15, no. 2 (2004): 143-151.

Rhodes James, Robert (ed.). Chips: The Diaries of Sir Henry Channon. New edition, London: Phoenix, 1993.

Rhodes James, Robert. Lord Randolph Churchill. London: Heinemann, 1994. 
Sack, James. From Jacobite to Conservative: Reaction and Orthodoxy in Britain, c. 1760-1832.

Cambridge: Cambridge University Press, 1993.

Scarrow, Susan E. 'Political Activism and Party Members', in Russell J. Dalton and Hans-Dieter Klingemann (eds), The Oxford Handbook of Political Behaviour. Oxford: Oxford University Press, 2007: $637-654$.

Stewart, Graham. Burying Caesar: Churchill, Chamberlain and the Battle for the Tory Party. London: Weidenfeld and Nicolson, 1999.

St John, Ian. 'Writing to the Defence of Empire: Winston Churchill's Press Campaign against Constitutional Reform in India, 1929-1935', in Chandrika Kaul (ed.), Media and the British Empire. Basingstoke: Palgrave, 2006: 108-119.

Swift, John. 'Randolph Churchill and the General Election in Preston, 1945: Bucking the Trend', Northern History, 48, no. 1 (2011): 123-144.

Thackeray, David. 'Home and Politics: Women and Conservative Activism in Early TwentiethCentury Britain', Journal of British Studies, 49, no. 4 (2010): 826-848.

Thompson, Andrew S. The Empire Strikes Back? The Impact of Imperialism on Britain from the MidNineteenth Century. London: Longman, 2005.

Turner, Michael J. 'Re-thinking Popular Conservatism in Liverpool: Democracy and Reform in the Later Nineteenth Century', in Michael J. Turner (ed.), Reform and Reformers in Nineteenth Century Britain. Sunderland: University of Sunderland, 2004: 157-174.

Waller, P.J. Democracy and Sectarianism: A Political and Social History of Liverpool 1868-1939. Liverpool: Liverpool University Press, 1981.

Williamson, Philip. National crisis and National Government: British Politics, the Economy and the Empire, 1926-1932. Cambridge: Cambridge University Press, 1992.

Williamson, Philip. 'The Conservative Party, Fascism and Anti-Fascism 1918-1939', in Nigel Copsey and Andrzej Olechnowicz (eds), Varieties of Anti-Fascism: Britain in the Inter-War Period. Basingstoke: Palgrave, 2010: 73-97. 